\title{
Level Readiness Participant Of Lifelong Learning (LLL) Program Venture Into Entrepreneurship
}

\author{
Mohd Shahzuan Ghazalan ${ }^{1}$, Noorazman Abd. Samad ${ }^{1}$, Fazlinda Ab Halim ${ }^{1}$, Nur Izeanty Hamidon ${ }^{1}$ and Tun Ili \\ Ayuni Ahmad Hariri ${ }^{1}$ \\ ${ }^{1}$ Faculty of Technical and Vocational Education, University Tun Hussein Onn Malaysia (UTHM), Malaysia
}

\begin{abstract}
This study aimed to investigate the perception of Lifelong Learning (LLL) program participants on their readiness to venture into entrepreneurship. Aspects of the level of readiness measured in this study includes; motivation, abilities knowledge and interests of the LLL program participants. The research sample consists of 235 respondents from LLL program participants. The research design was a survey using a quantitative approach that was analyzed using descriptive statistics-specifically frequency counts, percentages and mean. SPSS version 25.0 was used to analyze the data. The instrument used was a questionnaire which had a reliability coefficient of $\alpha=0.9$, indicating a very high instrument reliability. Findings reveal that the level of readiness of LLL program participants in entrepreneurial knowledge was at moderate level with mean value is 3.6. Meanwhile, readiness level of LLL program participants in terms of entrepreneurial interest was at high level with mean value is 4.1 . Readiness in terms of entrepreneurial motivation was at a high level with mean value is 4.2 . While readiness in terms of entrepreneurial abilities was moderately high level with mean value is 3.8. Thus, the researchers hope that the results obtained can be exploited by certain parties in order to improve the readiness of lifelong learning program participants in entrepreneurship, thereby producing quality entrepreneurs who can create more jobs to reduce the problem of unemployment in Malaysia.
\end{abstract}

\section{Introduction}

The Ministry of Higher Education in 2010 in the Executive Report Tracer reports that about 43.252 graduates are unemployed. Meanwhile, according to the National Statistics Department (2017) Report on Labor Force Statistics 2017, the percentage of unemployed people increased in Malaysia until July 2016 at a 3.5\% rate[1-3]. Unemployment will continue to remain if responsible party do not try to find new alternatives to build their own career or get involved in economic activities likes as entrepreneurship that can help to lead the economy as well as provide employment opportunities for others. There is much room to be exploited in the community for people to venture into various aspect of livelihood such as self-employment, business and entrepreneurship. The areas that can be pursued however requires initiative and persistence. Generally, among the causes of unemployment are lack of experience, low quality certificate / diploma / degree that are not recognized and do not meet stipulated standards, the lack of soft skills, too many immigrants and attitudes of local employees.

However, through self-development, aspects of the causes of unemployment triggered by the lack of readiness within an individual begins with the readiness measured against knowledge, interest, motivation and abilities in the field of employment. In this context, it is suggested that the labor force expand the scope of their careers and make entrepreneurship as a career path. Entrepreneurship will help graduates develop their own careers and will also solve the issue of unemployment by creating more job market[4,6]. Entrepreneurship has been recognized by most researchers as a solution to the problem of unemployment[4,5].Development in the field of entrepreneurship has a significant impact on the business world at the moment. The Government always pay attention to the development of future entrepreneurs who are resilient and competitive in the global market. This can be seen in a variety of programs and activities in every country's development agenda, including

* Mohd Shahzuan Ghazalan: gb150092@siswa.uthm.edu.my 
providing infrastructure to increase the number of entrepreneurs, especially among the indigenous people.

This effect has somewhat impacted participants Lifelong Learning Program at a community college to get a job after completing their program. As a solution, the ministry decided to utilize entrepreneurship as a means to solve the problem of unemployment in order to enable the Lifelong Learning program in community colleges to produce be more competent and resourceful entrepreneurs. Therefore, entrepreneurship is one of the areas of focus in community colleges due to the existence of the Lifelong Learning Program that has been provided. This is reflected in the government's efforts to produce entrepreneurs in various fields as an important agenda in ensuring that community colleges do not just produce graduates who are job seekers but also those who are knowledgeable to create jobs after graduation. This commitment can be seen with the establishment of Community College Entrepreneurship Center (PUSKOM) at the Department of Community Colleges and E-Tech Center in all Community Colleges throughout the country[7].

Thus, in 2011 community colleges have begun to see entrepreneurship as one of the branches of an alternative career choice for Lifelong Learning program graduates. Until 2013 the community college has produced nearly 400 entrepreneurs since the inception of the program. That effort continued throughout 2013 with community colleges organizing entrepreneurship challenges and competitions to develop entrepreneurship across community colleges. In this challenge, all community colleges were required to send at least one team. This effort is to nurture and cultivate entrepreneurship among participants in community colleges[7]. In addition, there were several approaches used to achieve the goal of creating a community of Malaysian entrepreneurial culture to attract Lifelong Learning program participants to entrepreneurship through entrepreneurship education in higher education. The goal was to provide knowledge, encouragement and entrepreneurial skills to these LLL participants[7,8]. The effectiveness of the program was viewed through the business performance in the third quarter of 2014 to the number of employees that showed a positive net balance of $5.4 \%[1,2]$.

Thus it was concluded that the program was able and adequate to nurture students to become entrepreneurs and change their mentality towards becoming selfemployed[9,11,13,14].

Whereas in previous years, community colleges only promoted entrepreneurship education among participants in an attempt to produce more entrepreneurs or to make entrepreneurship as an alternate career path for students. In addition, entrepreneurs are still being educated in community colleges to ensure that they continue to be successful and be able to share the benefits with their friends and other participants in terms of experience, career opportunities or business opportunities. This is also seen as fostering a culture of social entrepreneurship in the colleges indirectly[10,12,14]. However, the question becomes to what extent is the readiness of participants in the Lifelong Learning program towards entrepreneurship in order to reduce the percentage of unemployment in the country. Thus, this study was conducted to determine the level of LLL program participant's readiness in terms of knowledge, interest, motivation and abilities to become entrepreneurs.

\section{Research Objective}

The objective is:

i. Investigate the perception of Lifelong Learning program (LLL) participants on their readiness to venture into entrepreneurship.

ii. Aspects of the level of readiness measured in this study includes; knowledge, interests, motivation and abilities of the LLL program participants

\section{Methodology}

This study utilized a quantitative approach, specifically the survey research design to assess the readiness of Lifelong Learning program participants in the field of pastry towards entrepreneurship at community colleges Johor.

\subsection{Population and sample}

The population in this research is composed of Lifelong Learning program participants in the field of pastry at Batu Pahat Community College (KKBP), Tanjung Piai Community College (KKTP) and Ledang Community College (KKL). The population consists of participants in the Lifelong Learning program from Batu Pahat Community College, Tanjung Piai Community College and Ledang Community College who completed short courses in Pastries in 2015 according to statistics of participation in 2014.

The sample for the study from Batu Pahat Community College (KKBP), Tanjung Piai Community College (KKTP) and Ledang Community College (MPA) consisted of 236 participants, randomly selected using Krejcie and Morgan's table for sample size determination as a reference[15].

\subsection{Instrument}

The instrument used for this study was a questionnaire adapted by the researcher form previously developed instruments $[4,9,10]$. The survey method is often used in educational research, especially in research on entrepreneurship education in higher education institutions. The questionnaire includes two parts, part A and part B. A total of 4 items covering sections A was designed to solicit demographic data from respondents. Meanwhile, part B contains a total of 60 items related to the perception of Lifelong Learning (LLL) program participants about their level of readiness towards entrepreneurship venture in the field of pastry. Part B which measures readiness also consist of 4 constructs 
namely knowledge, interest, motivation and ability towards entrepreneurship venture.

In this study, face and content validity was carried out by three experts in the field of entrepreneurship to verify the quality and clarity of the questionnaire. A pilot study was also conducted in this research, using a sample of 32 Lifelong Learning (LLL) program participants in Segamat Community. Thus, 32 questionnaires were distributed to the participants of short courses in field pastry, and all questionnaires were successfully retrieved. However, during the process of entering data into SPSS, two questionnaires were not useable as the responses do not meet the criteria for usability and as a result were disposed. Making the total useable questionnaire for the pilot study to be 30 .

Data from the pilot study were prepared, cleaned and filtered for analysis using the software (SPSS V25.0). From the data analyzed, the reliability coefficient obtained for the instrument using Cronbach's Alpha reliability test was $\alpha=0.9$ which is more than the required alpha value for a highly reliable instrument, indicating that the questionnaire is highly reliable and capable of measuring the characteristics the researcher sought to measure (see Table 1).

Table .1. Results for Cronbach's Alpha

\begin{tabular}{|c|c|}
\hline $\begin{array}{c}\text { Score Cronbach's } \\
\text { Alpha ( } \alpha)\end{array}$ & $\begin{array}{c}\text { Level Cronbach's } \\
\text { Alpha } \\
\text { (Level of Reliability ) }\end{array}$ \\
\hline$\alpha=0.9$ & $\begin{array}{c}\text { Highly Reliable } \\
\text { Instrument }\end{array}$ \\
\hline
\end{tabular}

\subsection{Data analysis}

To analyze the data, the researcher used the software Statistical Package Social Science version 25.0 (SPSS V25.0) to answer four questions of the study. Descriptive statistics was used to analyze the data. More specifically, frequency counts, the mean and standard deviation were used to summarize and describe the findings of the study. Statistical analysis was carried out to investigate the mean level readiness of LLL program participants towards entrepreneurship venture in terms of knowledge, interest, motivation and ability.

\section{Findings}

The findings of the study which aimed at determining the level of readiness of LLL program participants from three community colleges in Johor towards entrepreneurship is presented in Table 1.

In overall, LLL program participant's level of readiness in terms of knowledge and abilities towards entrepreneurship venture is at medium-high level. While, in terms of their readiness towards entrepreneurial interest and motivation is at a high level (see Table 2).

\subsection{Level of Readiness}

In Table 2, the level of readiness for LLL program participants in terms of knowledge in entrepreneurship is at moderate level high at a mean value of 3.6. Meanwhile, their readiness level in terms of interest towards entrepreneurship was at a high level with mean values of 4.1, while their level of readiness in terms of their motivation towards entrepreneurial venture was at a high level with mean values of 4.2 and their level of readiness in terms of their ability to venture into entrepreneurship was at moderate-high level with mean values of 3.9 (see Table 2).

Table 2. Results for construct levels readiness

\begin{tabular}{|l|c|c|}
\hline \multicolumn{1}{|c|}{ Constructs } & Mean score & Level \\
\hline Knowledge & 3.6 & Moderate High \\
\hline Interest & 4.1 & High \\
\hline Motivation & 4.2 & High \\
\hline Ability & 3.9 & Moderate High \\
\hline
\end{tabular}

\section{Conclusion}

In conclusion, the Lifelong Learning (LLL) program participants showed a high level of entrepreneurship. It shows they have a tendency of becoming entrepreneurs. However, their level of readiness in terms of their knowledge of entrepreneurship needs to be improved. Concerned Community College stakeholders should play a role in designing and making continuous improvements in the curriculum to help the participants to be able to become more successful entrepreneurs in the future.

Thus, the researchers hope that the results obtained can be leveraged by these stakeholders in order to improve the implementation of Lifelong Learning (LLL) program participant's readiness for entrepreneurship, thereby producing quality entrepreneurs to contribute towards creating more jobs to reduce the problem of unemployment in Malaysia.

This paper was partly sponsored by the Centre for Graduate Studies UTHM.

Also, Acknowledgement to the MyBRAIN15 (MyPHD) because supporting researcher to finish this paper research. 


\section{Reference}

1. Jabatan Perangkaan Negara (2017), Perangkaan Tenaga Buruh, Malaysia, Julai 2017. Dicapai pada September, 10,2017 di

https://www.dosm.gov.my/v1/index.php?r=column/pdf Prev\&id=VzBiQ1BKSVc0S0hRN0x1RDBqR09BZz09

2. Jabatan Perangkaan Negara (2017), Statistik Kecenderungan Perniagaan, Suku Pertama 2017. February, 2017. Dicapai pada September, 282017 di https://www.dosm.gov.my/v1/index.php?r=column/pdf Prev\&id=eUd6T0YzWFU2aDRqeldQb2hMN1RGdz09

3. Laporan Siasatan Tenaga Buruh Usahawan Di Malaysia (2009), Perangkaan Tenaga Buruh, Malaysia. Siri 4 bil.1/2009 Dicapai pada November, 302014 di http://www.statistics.gov.my/portal/download_Labour/f iles/BPTMS/SIARAN_KHAS_(USAHAWAN_DI_M ALAYSIA).pdf

4. Othman (2009). Pelaksanaan Kaedah Pembelajaran Berasaskan Konsultasi dalam Pembudayaan Keusahawanan. Prosiding Kogress Pengajaran dan Pembelajaran di Awana Porto Malai Langkawi. 13-17

5. Othman \& Ishak (2009). Attitude Towards Choosing a Career in Entrepreneurship Amongst Graduates. Faculty of Education, Universiti Kebangsaan Malaysia,UKM. European Journal of Social Sciences, Vol 10, Num 3, pp. 1-16.

6. Osman (2007). Faktor-Faktor Yang Telah Mendorong Graduan Dan Alumni Universiti Teknologi Malaysia Menceburi Bidang Keusahawanan. 13-17

7. Pelan Stategik Pengajian Tinggi Negara 2007-2010 Fasa 1 (PSPTN), (2007) Membudayakan Pembelajaran Sepanjang Hayat. Dicapai pada Julai 23, 2014 dari http://www.mohe.gov.my/portal/images/utama/penerbit an/psptn.pdf

8. Buang \& Yusof (2006). Motivating Factors that Influence Class F Contractors to Become Entrepreneurs .Faculty of Education, Universiti Kebangsaan Malaysia, UKM. Jurnal Pendidikan, pp s $107-121$.

9. Hashim, Othman \& Buang (2009). Konsep Kesediaan Keusahawanan Berdasarkan Kajian Kes Usahawan Industri Kecil dan Sederhana (IKS) di Malaysia. Jurnal Pendidikan Malaysia. pp 187 - 203.

10. Adam \& Samsudin (2014). Pembangunan Keusahawanan dari Perspektif Kolej Komuniti. Prosiding Seminar Antarabangsa Kelestarian Insan 2014 (INSAN2014). pp $8-20$.

11. Hanapi, Nordinb \& Che Rus (2014). Unemployment Problem among Graduates of Technical Field: Competencies of the Graduates and Quality of the Education. Penerbit UTM Press. pp $1-5$

12. Halid (2012). Kesediaan Pelajar Politeknik Kejurteraan Elektrik Dalam Menceburi Bidang Keusahawanan. Jurnal Pendidikan Malaysia. pp 87 - 97
13 Nadzri, Shamsudin, \& M. Sabri (2010). FaktorFaktor Penyumbang Kepada Kejayaan Dan KegagalanPerusahaan Kecil Dan Sederhana (PKS) Bumiputera Di Malaysia. Jurnal teknologi Sains Sosial.Fakulti Pengurusan dan Muamalah. pp 1- 10

14 Yusof \& Shafie (2012). Konsep Kesediaan Keusahawanan Di Kalangan Pelajar Kolej Komuniti Bandar Penawar. JurnalPendidikan Malaysiapp 1- 17

15 Krejcie, R. V. \& Morgan, D. W. (1970). Determining Sample Size for Research Activities. Educational and psychology. 30: 607-610. 